\title{
Firm Export Diversification and Change in Workforce Composition
}

Citation for published version (APA):

Guillou, S., \& Treibich, T. (2017). Firm Export Diversification and Change in Workforce Composition. Maastricht University, Graduate School of Business and Economics. GSBE Research Memoranda No. 026 https://doi.org/10.26481/umagsb.2017026

Document status and date:

Published: 31/10/2017

DOI:

10.26481/umagsb.2017026

Document Version:

Publisher's PDF, also known as Version of record

\section{Please check the document version of this publication:}

- A submitted manuscript is the version of the article upon submission and before peer-review. There can be important differences between the submitted version and the official published version of record.

People interested in the research are advised to contact the author for the final version of the publication, or visit the DOI to the publisher's website.

- The final author version and the galley proof are versions of the publication after peer review.

- The final published version features the final layout of the paper including the volume, issue and page numbers.

Link to publication

\footnotetext{
General rights rights.

- You may freely distribute the URL identifying the publication in the public portal. please follow below link for the End User Agreement:

www.umlib.nl/taverne-license

Take down policy

If you believe that this document breaches copyright please contact us at:

repository@maastrichtuniversity.nl

providing details and we will investigate your claim.
}

Copyright and moral rights for the publications made accessible in the public portal are retained by the authors and/or other copyright owners and it is a condition of accessing publications that users recognise and abide by the legal requirements associated with these

- Users may download and print one copy of any publication from the public portal for the purpose of private study or research.

- You may not further distribute the material or use it for any profit-making activity or commercial gain

If the publication is distributed under the terms of Article $25 \mathrm{fa}$ of the Dutch Copyright Act, indicated by the "Taverne" license above, 


\section{Maastricht University}

Sarah Guillou, Tania Treibich

Firm Export Diversification and Change in Workforce Composition

RM/17/026

\section{GSBE}

Maastricht University School of Business and Economics

Graduate School of Business and Economics

P.O Box 616

NL- 6200 MD Maastricht

The Netherlands 


\title{
Firm Export Diversification and Change in Workforce Composition *
}

\author{
Sarah Guillou ${ }^{1}$ and Tania Treibich ${ }^{1,2}$ \\ ${ }^{1} \mathrm{OFCE}$ - SciencesPo Paris \\ ${ }^{2}$ Maastricht University and Sant'Anna School of Advanced Studies
}

October 9, 2017

\begin{abstract}
The objective of this paper is to show that part of the fixed cost of firms' trade expansion is due to the acquisition of new internal capabilities (e.g. technology, production processes or skills), which imply a costly change in the firm's internal labor organisation. We investigate the relationship between a firm's structure of labor, in terms of relative number of managers, and the scope of its export portfolio, in terms of product-destination varieties. The empirical analysis is based on a matched employeremployee dataset covering the population of French firms from tradable sectors over the period 2009-2014. Our analysis suggests that market expansion, and in particular export diversification, is associated with a change in the firm's workforce composition, namely an increase in the number of managerial layers and in the ratio of managers. We show how these results are consistent with a simple model where the complexity of a firm's operations increases in the number of product-destination couples exported, and where managers' role is to address the unsolved problems arising from such increased complexity of operations.
\end{abstract}

JEL classification: F16, E24, C14, D22.

Keywords: Export diversification, Managers, Occupations, Employer-employee data.

*This paper has benefited from comments of many seminar and conference participants at DEGIT 2017, ETSG 2015, CAED 2015, the Aarhus International Trade Workshop 2016 and the Maastricht University faculty seminar. We acknowledge financial support from the H2020 project: 'Innovation-fuelled, Sustainable, Inclusive Growth (ISIGROWTH)' under grant agreement 649186.) This work is also supported by a public grant overseen by the French National Research Agency (ANR) as part of the 'Investissements d'avenir' program (reference : ANR-10-EQPX-17, Centre d'accès sécurisé aux données, CASD) 


\section{Introduction}

While productivity differentials between exporters and non-exporters, documented by a vast empirical literature, are mostly motivated by the existence of sunk and fixed costs of exporting, the clear identification of such costs has not yet been obtained. ${ }^{1}$ Most explanations so far consider them as external to the firm. Indeed, the literature has put forward the country-specific nature of sunk costs, such as the cost to comply with foreign regulations, to establish distribution networks (Moxnes, 2010), to achieve high quality standards (Kugler and Verhoogen, 2012), or the cost associated with specific cultural and linguistic barriers (Egger and Lassmann, 2015). Instead, the objective of this paper is to show that part of the fixed cost of firms' trade expansion is due to the acquisition of new internal capabilities (e.g. technology, production processes or skills), which imply a (costly) change in the firm's internal labor organisation.

When starting to export or when expanding its export portfolio, a firm may hire whitecollar workers to establish new dedicated teams (Bernard and Jensen, 1997; Biscourp and Kramarz, 2007), or decentralize decisional processes to better deal with new production, marketing and distribution problems (Marin and Verdier, 2014). It has indeed been shown that exporting can be related to a shift in firms' employment structure toward higher skills (Serti et al., 2010; Iodice and Tomasi, 2015). It follows that such expansion in size and such a change in the overall nature of skills should require an increase in the complexity of the firm's management structure, as theoretically shown by Caliendo and Rossi-Hansberg (2012). Yet to our knowledge, the relation between export diversification and the labor organisation of the firm has not been yet empirically studied.

In the international economics literature, several theoretical mechanisms explaining why exporters' employees present higher skills have been put forward. The first hypothesis is that exporters benefit from increasing returns to skills, hence they have a greater incentive to adopt more advanced technologies of production (Yeaple, 2005; Helpman et al., 2010; Amiti and Davis, 2012) or to produce higher quality products (Verhoogen, 2008). Closer to our framework, Caliendo and Rossi-Hansberg (2012) have shown that exporters would be required to change their internal labor organization in order to raise their productivity and sustain the trade cost. In their model, firms that start exporting increase the number of layers of management.

The empirical relation between trade and firms' skill structure has been studied in different contexts (Bernard and Jensen, 1997; Biscourp and Kramarz, 2007; Serti et al., 2010; Iodice and Tomasi, 2015). Their results point to the fact that, because exporters demand more high-skilled workers, this induces a rise in their wage bill, explaining the wage

\footnotetext{
${ }^{1}$ Some noticeable examples of studies estimating the sunk costs of exporting are Roberts and Tybout (1997) and Das et al. (2007).
} 
premium. ${ }^{2}$ Although these studies also investigate the labor characteristics of exporters with respect to non-exporters, their aim is to explain the overall differences in wages, skills and productivity. Thus they do not consider the way these different types of workers are organized within the firm, which instead requires detailed information on firms' distribution of occupations and skills, recently made available in matched employer-employee datasets, as we use here.

In the literature on multi-product firms, a firm's range of products is determined by both demand and supply elements. Bernard et al. (2010) consider stochastic shocks to firm productivity and to consumer taste, Eckel and Neary (2010) distinguish between the competition and market-size effects, and Mayer et al. (2014) study the effect of competition and distance of the products to the core competences of the firm. Caselli et al. (2014) follow Eckel and Neary (2010) and Mayer et al. (2014) by considering the distance to the plant's core expertise which defines its productivity level. The important mechanism put forward in this discussion is that a product's distance to the core competences of the firm is assumed to drive its cost. Indeed, for a given knowledge level, the firm reduces its productivity when enlarging its product scope. We generalize this framework to the addition of export varieties (product-destinations couples). For instance, differences in customers' tastes and habits could also lead to adjust the product itself. In that case, differenciation-perdestination becomes similar to adding a new product to a firm's portfolio. Building on the above insights, why would export expansion, i.e. an increase in the number of products and/or destinations impact a firm's labor organisation?

The first part of the answer relates to the concept of complexity of products and destinations. By adding products and/or destinations, the firm is more likely to encounter production, distribution or marketing 'problems' which need to be dealt with at a higher management level. Reaching a new destination also means facing new administrative rules, requires prospecting new distribution networks, and fitting new customers habits. All these issues call for additional competences. In parallel, when a firm adds new products, it also augments the need for adapting both skills and production processes. Thus, similarly to Mayer et al. (2014), we also associate changes in costs to modifications of the product (here, varieties) portfolio, but we assume that they depend on their complexity, which is a more general assessment than the distance to the core competences of the firm. Second, trade diversification also has a scale dimension: it is costly because the firm has to manage a higher number - a larger scope - of different products and destinations, raising the diversity of problems to deal with. It follows that both qualitative and quantitative aspects

\footnotetext{
${ }^{2}$ Technological upgrading following trade liberalization has also been documented by Bustos (2011) in the case of Argentina. In turn, Verhoogen (2008); Helpman et al. (2010); Baumgarten (2013) have shown that the extension of trade, as a consequence of trade liberalization for instance, increases wage inequality within industries.
} 
of trade diversification increase management complexity and should impact the internal labor organisation of the firm.

Yet, building on the insights from Mayer et al. (2014), the impact of trade diversification on the necessity to implement organisational changes within the firm may depend on how much more complex the new problems caused by trade diversification are with respect to the "business-as-usual" activities in the firm. As we show in our model, a trade-off between the motivation to add varieties in order to gain from economies of scope, and the rise in costs due to the organisational changes required in order to manage such increased complexity of operations may emerge. Therefore an empirical investigation is required to test the relation between the use of managers and the export diversification behaviour of firms.

Our work contributes to the literature in two important ways. First, we show that firms with a greater number of export product-destination varieties have on average a greater number of management layers, and that this result still holds after controlling for firm size (total sales). We argue that the increasing complexity that comes with greater trade diversification may constitute an important component of the sunk and fixed costs of exporting. This is especially true if large upfront investments are required for restructuring a firm's organization, and if the cost of maintaining management layers is inelastic to variations in output volume. Second, we show that trade matters for a firm's hierarchical structure not only because it expands its market size (Caliendo and Rossi-Hansberg, 2012), but also because it increases the complexity of a firm's operations. Empirically, this is suggested by some evidence that the share of workers in upper layers increases non-homothetically with export diversification. To illustrate this intuition more formally, we present a simple model where the complexity of a firm's operations depends on the number of product-destination flows generated, and where firms can choose to add managers to deal more efficiently with this complexity. In the model, because the number of managers is less sensitive to the quantity produced than the number of blue-collar workers, it acts as a fixed cost. Third, our work contributes to the growing litterature on the importance of managers for firm performance by proposing a reason why managers are important for firm performance. Since managers' skills are needed for trade diversification, larger and more globalised firms would hire more managers, and with higher skills. Our results support those of Bender et al. (2017) who state that it is the skills of the group of managers which matter most to translate the best management practices into higher firm performance.

Our empirical study is based on three French administrative datasets, and it focuses on the relationship between a firm's organization and export activity, exploiting employeelevel data to reconstruct the management structure of individual firms. ${ }^{3}$ Records of ex-

\footnotetext{
${ }^{3}$ As in Caliendo et al. (2015) we measure the 'management structure' from the occupational layers that
} 
porters' individual transactions are used to measure the scope of a firm's export portfolio. Beyond the changes associated to starting to export, firm export expansion can be realized at the extensive margin through the addition of products newly exported or destinations newly reached. Finally, balance sheet data allow us to control for other firm-level characteristics. We find that firms expanding their export portfolio have a higher probability to add managerial layers, after controlling for firm growth. Finally, and in line with the model, the ratio of managers with respect to other workers increases when the portfolio of exported products and destinations expands.

The paper is structured as follows. Section 2 presents our rich dataset which compiles several data sources. Section 3 displays the descriptive statistics which illustrate our intuition regarding the relation between trade diversification and labor organisation. Section 4 outlines a simple theoretical framework of a multiproduct firm which supports our empirical evidence. Section 5 tests and discusses the results. Section 6 concludes.

\section{Data}

\subsection{Datasets}

Three main sources of data are required. The first one, the 'Déclaration Annuelle de Données Sociales' (DADS), gathers compulsory information provided by firms each year to the social administration about their employees. Each observation corresponds to a combination of a worker and an establishment, both with a unique identifier. The variables of interest are the workers' gross wage, number of hours worked, type of contract (mainly used for data cleaning purposes) and occupational category (PCS, 'Professions et Catégories Socioprofessionnelles', 2003) at the 4-digit level. The second dataset gathers balance-sheet and performance variables per firm (FARE). Both DADS and FARE are provided by the French National Institute of Statistics (INSEE) and cover the universality of French firms, with the exception of firms with no employees, or belonging to the agricultural sector. The third dataset is provided by the French customs administration (Custom-DGDDI) and records all flows of imports and exports by product, destination and firm. It covers the trade of merchandises and reports, at the product-firm level, the quantity (in $\mathrm{Kg}$ ), the country of destination, the product category (CN8), and the value of the export flow. This dataset allows us to trace precisely firms' performance in foreign markets (i.e., their portfolio of exported products, their prices proxied by their unit-values, patterns of entry and exit to/from foreign markets, and variations in exported value over time).

All three datasets can be matched by using the firm identifier (SIREN) into a longitudinal dataset covering the period 2009-2014. Note that we restrict our analysis to the compose a firm's workforce. 
Table 1: Observations description across samples, after cleaning. Manufacturing, retail and IT sectors, 2009-2014.

\begin{tabular}{lccccc}
\hline \hline Year & \multicolumn{3}{c}{$\begin{array}{c}\text { DADS \& FARE } \\
\text { (sample 1) }\end{array}$} & $\begin{array}{c}\text { sample 1 \& Customs } \\
\text { (sample 2) }\end{array}$ \\
\cline { 2 - 4 } \cline { 3 - 4 } & All & Non-exporters & Exporters & Exporters (customs) \\
\hline 2009 & 432,877 & 329,432 & 103,445 & 55,150 \\
2010 & 428,162 & 323,873 & 104,289 & 55,399 \\
2011 & 423,055 & 331,118 & 91,937 & 51,975 \\
2012 & 420,154 & 329,366 & 90,788 & 52,084 \\
2013 & 416,539 & 326,814 & 89,725 & 51,370 \\
2014 & 413,626 & 323,971 & 89,755 & 49,115 \\
\hline Total nb. obs. & $2,534,413$ & $1,964,574$ & 569,839 & 315,093 \\
Total nb. firms & 640,390 & 446,675 & 193,715 & 81,880 \\
\# Firms alw. present & 255,134 & - & - & - \\
\# Firms alw. exporters & - & - & 85,820 & 46,114 \\
\hline \hline
\end{tabular}

main tradable sectors which include manufacturing (NACE rev.2 sectors 10-33, C), Retail (NACE rev.2 sectors 45-47, G) and ICT services (NACE rev.2 sectors 58-63, J). This is driven first by the use of tradable goods statistics instead of services and also because focusing on manufacturing only would exclude numerous firms which export goods, although belonging to the services sector. Moreover, the theoretical mechanisms we build on relate to firms' needs to reorganize production when facing ability constraints (see Caliendo and Rossi-Hansberg, 2012; Caliendo et al., 2015), which is not solely bound to manufacturing firms. We alternatively use two samples of firm-level data, depending on the object at hand. When studying the decision to export and its consequence on the labor organisation of the firm, we require firms to be present both in the FARE and DADS datasets (sample 1). Then, when analysing the trade diversification behaviour of firms, focusing on exporters only, we additionally impose that the firm is also observed in the Customs dataset, leading to a smaller set of observations (sample 2), and excluding de-facto the smaller exporters who do not report their trade flows.

Table 1 describes the population of firms in the two samples. We consider 2,534,413 observations, corresponding to 640,390 firms and 193,715 exporters (sample 1). Further, we can study the export diversification behavior of nearly half of the latter group $(81,880$ exporters in sample 2).

\subsection{Construction of variables}

Our aim is to assess the structure of firms' labor organization, based on the available information about employees' occupational category, following Caliendo et al. (2015). Each 
employee in the DADS database belongs to a "hierarchical layer" based on the first digit of his occupational category. Coherently with the definition of Caliendo et al. (2015), we identify four possible layers from the bottom of the hierarchy (layer 1) to the top (layer 4). The first layer corresponds to clerks and production workers (blue-collar workers); layer 2 corresponds to intermediate professions and technicians (supervisors); layer 3 corresponds to executives or senior staff (white collars) and layer 4 is the top management (CEOs, directors). In order to focus on managerial functions, we then group layers into "production occupations" (layers 1 and 2) and "managerial occupations" (layers 3 and 4). We exclude firms which do not have the first layer of occupations ( $9 \%$ of observations), i.e. without production occupations. Starting from the DADS employee database, we then construct firm-level variables by aggregating the information over each firm-SIREN. We then merge such variables with the FARE and Customs dataset at the firm level.

We have two sources of information regarding exporters, with different sample size and variables. The FARE dataset registers the total value of exports for all firms, with no legal obligation. Instead, firms are legally bound to provide the customs institution information about their trade flows (by product and destination) above a specified threshold value. ${ }^{4}$ We define as exporters firms declaring export sales in the FARE dataset, so as to include smaller exporters as well.

\section{Empirics about labor organization and export behavior}

Starting from the model of Caliendo and Rossi-Hansberg (2012), Caliendo et al. (2015) brought a large amount of empirical evidence on production hierarchies. Focusing on the case of French manufacturing firms over the period 2002-2007, they find support to the theoretical model by Caliendo and Rossi-Hansberg (2012): firms' important growth events are associated with an increase in their number of hierarchical layers. Following a pyramidal firm structure, growth in number of employees in the existing layers requires to strengthen the hierarchy at the firm level, e.g. by assigning new managerial positions.

Although our data are coming from the same source, we cover a more recent period. After checking that the results by Caliendo et al. (2015) are also validated in our data, we bring additional evidence regarding the organizational structure of exporting firms. Our focus is put on exporters' trade diversification in terms of products and destinations and its impact on changes in the organization of their labor force, in particular by observing the change in the presence and composition of managerial layers relative to production ones.

\footnotetext{
${ }^{4}$ Indeed, export sales within the European Union need to be declared only if the yearly firm export sales are above $€ 460,000$ for years 2011 and 2012, and $€ 150,000$ before 2011 .
} 


\subsection{Firm characteristics and hierarchical structure}

We describe below how the firms in our sample are distributed according to the structure of their hierarchical layers, by aggregating over firms' employee characteristics. The presence of a layer within a firm is defined by at least one employee belonging to the corresponding occupational level. We observe heterogeneity across firms along four dimensions: their total number of layers, the presence of managerial layers or not, their size category and their export status (exporters representing approximately $25 \%$ of the dataset, see Table $1)$.

We observe that if most firms have only a layer of "blue collars" (1-layer), ${ }^{5} 5 \%$ have a complete set of hierarchical layers (4-layers) in our sample. Table 2 also shows that the distribution of firms conditional on their number of layers differs for exporting firms : more exporters - $47 \%$-have 3 or 4 layers, compared to $24 \%$ in the general population. Thus the hierarchical structure of exporting firms seems to be more elaborated than the one of non-exporting firms.

In what follows we simplify the picture by focusing on two levels only: the "production occupations" (only layer 1 or layers 1 and 2) or "managerial occupations" too (layer 3, layer 4 or layers 3 and 4 ). Thus instead of counting the number of layers, no matter the level, we identify firms according to the presence of white collar occupations ("managerial occupation") or not (the bottom part of Table 2). When using such categorisation, the distribution of firms is flipped around when comparing exporters (61\% of firms with managerial occupations) to the general population (only 36\%). Not surprisingly, the hierarchical organisation of firms is also explained by their size category: if almost $100 \%$ of the largest firms have managerial occupations, only $36 \%$ of the smallest firms (53\% of the smallest exporters) do. Note that we can only observe employees who earn a salary, so we miss manager-owners (who do not earn a salary). This is why firms whithout a layer of managers are mostly small firms in which the owner is the unique manager.

Besides these static characteristics, we are interested in the labor organisation dynamics, as we will study its relation with the export diversisifaction. How often do firms add or drop a layer of management? Table 3 shows that most firms kept a stable organizational structure between 2009 and 2014. Yet, exporters are more likely to change it. If we suppose that adding a managerial layer can be associated with firm expansion in general, and, export expansion in particular, what can explain that a firm eliminates managers? Although this is beyond the scope of this paper, dropping managers' layer may be observed in firms close to exiting or in a process of rationalisation of the group organisation they belong to.

Table 4 displays firm characteristics conditional on the presence of managerial occu-

\footnotetext{
${ }^{5}$ Note that in our cleaned sample all firms have at least one layer, i.e. the lowest one.
} 
Table 2: Percent of observations by number of layers and presence of managers conditional on size classes, 2009-2014.

\begin{tabular}{|c|c|c|c|c|c|}
\hline Size class & {$[1-20[$} & {$[20-50[$} & {$[50-250[$} & {$[250-+[$} & all \\
\hline & \multicolumn{5}{|c|}{ All firms } \\
\hline 1-layer & 49.3 & 9.9 & 1.8 & 0.2 & 51.8 \\
\hline 2-layers & 31.2 & 21.0 & 8.3 & 2.2 & 24.2 \\
\hline 3-layers & 17.5 & 48.7 & 52.4 & 47.6 & 19.0 \\
\hline 4-layers & 2.0 & 20.5 & 37.6 & 50.0 & 5.1 \\
\hline \multirow[t]{2}{*}{ Total } & 100 & 100 & 100 & 100 & 100 \\
\hline & \multicolumn{5}{|c|}{ Exporting firms } \\
\hline 1-layer & 29.4 & 2.8 & 0.5 & 0.7 & 27.1 \\
\hline 2-layers & 38.2 & 13.7 & 3.8 & 3.8 & 26.3 \\
\hline 3-layers & 26.9 & 54.5 & 51.8 & 51.8 & 32.3 \\
\hline 4-layers & 5.6 & 28.9 & 43.9 & 43.9 & 14.3 \\
\hline \multirow[t]{2}{*}{ Total } & 100 & 100 & 100 & 100 & 100 \\
\hline & \multicolumn{5}{|c|}{ All firms } \\
\hline Without managerial occupations & 64.4 & 21.9 & 6.4 & 1.7 & 63.7 \\
\hline With managerial occupations & 35.6 & 78.1 & 93.6 & 98.3 & 36.3 \\
\hline \multirow[t]{2}{*}{ Total } & 100 & 100 & 100 & 100 & 100 \\
\hline & \multicolumn{5}{|c|}{ Exporting firms } \\
\hline Without managerial occupations & 47.0 & 10.5 & 2.4 & 0.3 & 39.5 \\
\hline With managerial occupations & 53.0 & 89.5 & 97.6 & 99.7 & 60.5 \\
\hline Total & 100 & 100 & 100 & 100 & 100 \\
\hline
\end{tabular}

Table 3: Change in the presence of a layer of managers between 2009-2014.

\begin{tabular}{rrr}
\hline \hline & \multicolumn{2}{c}{ Percent } \\
\cline { 2 - 3 }$\Delta$ Managerial & All firms & Exporters \\
occupations & & \\
\hline Dropping: -1 & 5.02 & 6.51 \\
No change: 0 & 90.63 & 87.60 \\
Adding: +1 & 4.35 & 5.89 \\
\hline \hline
\end{tabular}


pations. Not surprisingly, firms with managers are larger and this, considering different size proxies. They also have a higher probability to export, and conditional on exporting, have a higher export intensity. Relatedly, and given the well-known size-wage and exportwage premia, we also find a positive correlation between the presence of managers among empoyees and mean hourly wage. This is coherent with the work of Caliendo et al. (2015) on hierarchical layers.

Table 4: Mean characteristics of firms by hierarchical structure, 2009-2014. (value added, wages and sales are deflated with sectoral price indexes at the 2-digit level.)

\begin{tabular}{|c|c|c|c|c|c|c|}
\hline \multirow[t]{2}{*}{ \# Layers } & \multicolumn{3}{|c|}{ Firm size proxies } & \multicolumn{2}{|c|}{ Export performance } & \multirow{2}{*}{$\begin{array}{c}\text { Labor charact. } \\
\text { Hourly } \\
\text { wage }\end{array}$} \\
\hline & $\begin{array}{c}\text { Nb. } \\
\text { employees }\end{array}$ & $\begin{array}{l}\text { Value } \\
\text { added }\end{array}$ & Sales & $\begin{array}{c}\text { Exp. } \\
\text { propensity }\end{array}$ & $\begin{array}{c}\text { Exp. } \\
\text { intensity }\end{array}$ & \\
\hline Without managerial occup. & 5.4 & 151.7 & 639.8 & 0.14 & 0.13 & 11.22 \\
\hline With managerial occup. & 47.4 & $2,185.6$ & $11,035.5$ & 0.37 & 0.15 & 17.14 \\
\hline $\mathrm{t}$ test & $* * *$ & $* * *$ & $* * *$ & $* * *$ & $* * *$ & $* * *$ \\
\hline
\end{tabular}

If the distinction between firms having a managerial layer and those who don't is relevant, could we characterize the labor organisation in a more continuous way? To do so, we compute the managers ratio, first with the ratio of employees in the managerial versus the production layers, and second with the ratio in terms of number of occupations. An occupation relates to the nature of jobs and is defined at a very detailed level (4 digits). Table 5 confirms the distinct pattern of labor organisation between exporters and non-exporters: the former present a higher ratio of number of managers and number of managerial occupations.

Table 5: Ratio of managers vs. workers, 2009-2014.

\begin{tabular}{lcc}
\hline \hline & Managers' ratio & \# Obs. \\
\hline by nb. employees & & \\
Non-exporters & 0.529 & 574,815 \\
Exporters & 0.712 & 344,097 \\
t-test & $* * *$ & \\
\hline by nb. occupations & & \\
Non-exporters & 0.521 & 575,526 \\
Exporters & 0.547 & 344,883 \\
t-test & $* * *$ & \\
\hline \hline
\end{tabular}

We summarize the first set of statistical results as follows:

Empirical fact 1 (2) The organisational structure of exporting firms is more complex than the one of non-exporting firms, as the former are more likely to have managerial occupations and a higher share of managers relative to workers. 


\subsection{Number of products, destinations and layers}

In a next step, we measure precisely the diversification intensity of exporters, with the aim of linking the cost of diversification to firms' labor organization. Indeed, two exporting firms with similar overall export sales would differ in their diversification intensity if they serve a different number of product-destination couples, which we label as varieties. Thus the number of export varieties delivers information about a firm's trade diversification irrespective of its export intensity. A firm which sells one product (defined at the 8-digit level) to two different destinations exports two varieties. By using export data coming from the French customs (referring to our sample 2, see Table 1), we track the total number of product-destination couples (i.e. varieties) a firm exports per year. ${ }^{6}$

The number of varieties per firm ranges from 1 to 17455 , with $50 \%$ of exporters shipping less than 7 varieties and $95 \%$ less than $164 .{ }^{7}$ To complement the information about the number of varieties, we compute a Herfindahl-Hirschmann Index (HHI) at the level of the firm to appreciate the extent of the diversity of varieties in terms of exported value. For instance, a firm that exports two varieties such as it splits its export value in two equal shares is more diversified than a firm which exports $98 \%$ of its sales in variety A and $2 \%$ in variety B. Therefore, we consider that the higher the HHI, the lower the diversification. By construction, the HHI ranges between 0 and 1 . We then cross the information on export diversification with the labor characteristics of the firm (having a layer of managers or not). We expect that a larger number of varieties is positively correlated with a demand in complex management. It follows that we should find a positive correlation between the presence of managerial occupations and the number of varieties, and a negative correlation with the HHI. We also compute the number of new varieties in year $t$ per firm - which is such that it has never been present in the varieties portfolio of the firm the years before $t$ (for the span of years we observe in our dataset). ${ }^{8}$

We consider two levels of disaggregation. Varieties defined at 8-digits level means that we define a variety with respect to the finest level of product disaggregation (NC8) while varieties at the 4-digits level refers to the SH4 disaggregation. The more the classification is disaggregated and the more consecutive identifiers refer to products close to each other. So

\footnotetext{
${ }^{6}$ The results presented in this paper are robust when using instead firms' total number of exported products or destinations as the diversification measure. Results are available from the authors upon request.

${ }^{7}$ The number of products per firm ranges from 1 to 835 , with $50 \%$ of exporters shipping less than 4 products and $95 \%$ less than 45 . The number of destinations per firm ranges from 1 to 168 , with $50 \%$ of exporters shipping to less than 4 destinations and $95 \%$ less than 43 destinations. We also group the destinations by geographical area. Geographical areas are: Europe, Africa, Asia, North-America, Central and South America, Middle-East, Oceania and Others. The number of areas per firm ranges from 1 to 8 , with $50 \%$ of exporters shipping to less than 2 areas and $95 \%$ less than 7 areas.

${ }^{8} \mathrm{~A}$ variety cannot be a new one in the year the firm enters the database.
} 
a change in 8-digit product without a change in the 4 first digits is a weaker diversification than it is if the change occurs at the 4-digits level. Considering two levels of disaggregation allows to test the impact of the intensity of diversification. Note that we could have get down to a 2-digits level which a change will imply an even more radical diversification. But at this level, the diversification is too rare to be be studied properly.

Table 6 confirms that a firm with managers is more likely to export more products and/or ship to more different destinations. Moreover, the presence of managers is also associated with a higher level of new varieties on average. As expected, all indicators of diversification are positively correlated with the presence of managers occupations. Moreover, the HHI in terms of varieties is lower with managers than without (recalling that a high HHI value is a signal of weak diversification). This evidence confirms our intuition that a more diversified firm - which really splits its production and shipment over several product-destination couples in relatively more equal weights - has a higher need for managers.

Table 6: Average export diversification indicators conditional on managerial occupations, 2009-2014.

\begin{tabular}{|c|c|c|c|c|c|c|}
\hline & \multicolumn{2}{|c|}{ \# Varieties } & \multicolumn{2}{|c|}{ \# New Varieties } & \multicolumn{2}{|c|}{ HHI varieties } \\
\hline & NC8 & SH4 & $\mathrm{NC} 8$ & SH4 & $\mathrm{NC} 8$ & SH4 \\
\hline Without managerial occupations & 9.22 & 6.96 & 4.22 & 2.72 & 0.64 & 0.64 \\
\hline With managerial occupations & 47.58 & 31.41 & 15.8 & 8.80 & 0.46 & 0.48 \\
\hline t-test & $* * *$ & $* * *$ & $* * *$ & $* * *$ & $* * *$ & $* * *$ \\
\hline
\end{tabular}

The above indicators show that French exports cover a very broad portfolio of varieties. However how many firms modify their portfolio over time? Only $32.4 \%$ of firms keep their portfolio of varieties unchanged during the 5 -year period while $10.4 \%$ change more than $50 \%$ of their porfolio. In addition, when considering varieties at the 4-digits level, changes are less frequent (cf. Table 7).

Table 7: Changes in firms'trade portfolio between 2009-2014.

\begin{tabular}{rc}
\hline \hline$\Delta \#$ Varieties & Percent. of firms \\
\hline$<-75 \%$ & 5.6 \\
]$-50 \%,-75 \%]$ & 7.8 \\
] $0,-50 \%]$ & 18.6 \\
$0 \%$ & 32.4 \\
] $0,50 \%]$ & 11.7 \\
] $50 \%, 100 \%]$ & 10.4 \\
$>100 \%$ & 13.7 \\
\hline \hline
\end{tabular}

As a further step, we group exporting firms per quartile of number of varieties, control- 
ling for firm size. Indeed, we want to disentangle as much as possible the labor organisation pattern due to expansion (as measured by firm size) with respect to the role of management complexity due to trade diversification. Table 8 shows that the share of firms with managerial occupations increases with the quartiles. The last column of Table 8 presents the ratio of managers. The rate also increases with the number of varieties that a firm exports, indicating that such diversification is associated with a modification of its internal labor organization up to the third quartile, and stabilizes afterwards.

Table 8: Managers' intensity per quartile of varieties, controlling for firm size, 2009-2014.

\begin{tabular}{llllll}
\hline \hline & \multicolumn{2}{c}{$\begin{array}{c}\text { \% Firms with } \\
\text { managerial occup. }\end{array}$} & & \multicolumn{2}{c}{ Managers' Ratio } \\
\cline { 2 - 3 } \cline { 5 - 6 } & NC8 & SH4 & & NC8 & SH4 \\
\hline Q1 \# varieties & 0.62 & 0.61 & & 0.33 & 0.32 \\
Q2 \# varieties & 0.68 & 0.66 & & 0.35 & 0.34 \\
Q3 \# varieties & 0.74 & 0.74 & & 0.39 & 0.39 \\
Q4 \# varieties & 0.83 & 0.83 & & 0.38 & 0.39 \\
Q5 \# varieties & 0.93 & 0.93 & & 0.37 & 0.37 \\
\hline \hline
\end{tabular}

The additional statistics lead to formulate the following second empirical fact.

Empirical fact 2 (2) Among exporters, the presence and intensity of managerial occupations are positively associated with trade diversification.

In what follows, we present the theoretical mechanisms which could explain these two empirical facts, We propose a theoretical framework which links multiproduct firms' relative number of managers with trade diversification decisions.

\section{Model}

Our aim is to assess the impact of an increase in trade diversification on the labor organization of the firm. We define export diversification as the addition of a new productdestination couple to the firm portfolio of products and destinations. Export diversification is very close to an increase in export performance but may be different in terms of organization from a rise in the export intensive margin.

Mayer et al. (2014) have modeled how a firm's range of exported products is affected by competition across market destinations. They find that firms react to increased competition by focusing on their "core", best-performing products. It supports the idea that the product mix and the destination portfolio of exporters are not independent but coevolve. Moreover, their model implies that foreign competition changes the organisation of competences in the firm. We augment the model by Mayer et al. (2014) with the hindsights 
from Caliendo and Rossi-Hansberg (2012) on the relation between market expansion and firm reorganization, and from Ottaviano and Thisse (1999) on the firm's revenue side. Caliendo and Rossi-Hansberg (2012) propose a model of the organization of knowledge and labor within a firm in response to an exogenous demand for differentiated products. The organization of knowledge and labor involves deciding the number of managers to solve problems encountered by the employees. Contrary to Caliendo and Rossi-Hansberg (2012), we model only two layers of employees: workers and managers. Given an exogenous distribution of problems faced by the firm, its productivity level depends on the number of managers it uses and on managers' skills.

In what follows, we describe the demand (section 4.1) and the supply sides (section 4.2) of the model. The predictions of our theoretical framework will then be tested in our empirical analysis (section 5) below.

\subsection{The demand side}

We model the demand as in Mayer et al. (2014). The utility function of an individual consumer $c$ depends on the consumption of a numeraire good $q_{0}^{c}$ and on the consumption of differentiated products $q_{i}^{c}$ distributed over a continuum $\Omega$ :

$$
U=q_{0}^{c}+\alpha \int_{i \in \Omega} q_{i}^{c} d i-\frac{1}{2} \gamma \int_{i \in \Omega}\left(q_{i}^{c}\right)^{2} d i-\frac{1}{2} \eta\left(\int_{i \in \Omega} q_{i}^{c}\right)^{2} d i
$$

where the demand parameters $\alpha, \gamma$ and $\eta$ are all positive. The larger is $\gamma$, the greater is consumers' love for variety, and the faster their utility increases when they smooth consumption over varieties $i$ in $\Omega$. The parameter $\eta$ determines the degree to which the aggregate consumption of all varieties reduces the marginal utility from the consumption of individual varieties. This utility function generates the following inverse demand for individual varieties:

$$
p_{i}=\alpha-\gamma q_{i}^{c}-\eta Q^{c}
$$

where $p_{i}$ is the price of variety $i$ and $Q^{c}$ is the consumer's aggregate consumption of all differentiated varieties. By inverting (2) we obtain the following linear demand:

$$
q_{i} \equiv L q_{i}^{c}=\frac{\alpha L}{\eta N+\gamma}-\frac{L}{\gamma} p_{i}+\frac{\eta N}{\eta N+\gamma} \frac{L}{\gamma} \bar{p}
$$

where $q_{i}$ is the aggregate consumption of variety $i$ across $L$ consumers in the market. $N$ is the number of differentiated varieties in that market, and $\bar{p}=\frac{1}{N} \int_{i \in \Omega^{*}} p_{i} d i$ is the average price for differentiated goods. $\Omega^{*}$ is the subset of varieties in the market whose price $p_{i}$ is low enough not to drive demand in eq. (3) to 0 . Notice that only varieties with price $p_{i}<p^{M A X}$, where $p^{M A X} \equiv \frac{1}{\eta N+\gamma}(\gamma \alpha+\eta N \bar{p})$, have positive demand. 


\subsection{The supply side}

We model the variety portfolio of a firm as a set of product-destination couples $\Theta=$ $[1, \ldots, \theta]$ where elements are indexed by a continuous series of integers increasing in the cost of producing each variety. By assuming that it is easier for the firm to operate in the domestic market, a firm which sells only on the domestic market has a narrower set of product-destination couples. An exporter has at least two product-destination items: one product and two destinations (domestic and foreign). The last element of the set $\Theta$ represents the product-destination with the highest cost of production for the firm. The same product exported to different markets may have different positions in $\Theta$, reflecting adjustment costs to meet destination-specific tastes. ${ }^{9}$ We also include economies of scope through a fixed cost $G$ which drives the decision on the product range. More precisely, the product range is the firms' number of varieties, $\theta$, which is also the level of diversification and product-complexity of the firm.

We assume that exporters follow a pecking order when adding new product-destination couples to their portfolio: they initially export to 'easier' product-destinations and later on they add more difficult items to their portfolio. ${ }^{10}$ This assumption allows us to relate an exporters' optimal managerial structure to the most difficult product exported $\theta$. In addition to the fixed cost $G$ we model the cost associated with the difficulty of producing additional varieties. In what follows, we model a representative firm and we drop the exponent $j$ to lighten the presentation. Note however that variables are firm-specific.

Each production possibility is associated with a random level of difficulty. Therefore the blue-collar worker must solve each problem in order to deliver one unit of output. The probability that a worker solves the problem is described by the function:

$$
F(z, \theta)=1-e^{-\left(\frac{1}{\theta}\right) z}
$$

where $z$ is the skill level of each blue-collar worker. If the skill of the firm's worker increases, the probability to encounter an unsolved problem decreases. As the firm extends its export portfolio toward more difficult product-destination items (i.e, larger $\theta$ ), the last exported item generates more difficult problems to solve. This is reflected by the fact that $F(z, \theta)$ decreases in $\theta$. A greater number of unsolved problems determines a greater number of wasted production possibilities, and a larger marginal cost.

Let's assume that the firm can hire a number of managers $n_{m}$ that are more skilled than workers such that $z_{m}>z$. With an additional organization layer, the problems unsolved by the blue-collar workers can be passed on to at least one manager in each firm,

\footnotetext{
${ }^{9}$ The cost side of this section is based on Mayer et al. (2014) with the hindsights from Caliendo and Rossi-Hansberg (2012). The revenue side is based on the framework from Ottaviano and Thisse (1999).

${ }^{10}$ This assumption is supported by empirical evidence on Mexican multi-product exporters provided by Iacovone and Javorcik (2010).
} 
who would use $h$ units of time to solve the problem. Thus $z_{m}$ determines the production constraint at the firm level:

$$
n_{w} A\left(1-e^{-\left(\frac{1}{\theta}\right) z_{m}}\right)>q
$$

where $A$ is the firm-specific average productivity that is common across all products produced by the firm. More specifically, $A$ is the average number of 'production possibilities' generated by a worker of the firm in one unit of time. $q$ is the total production of the firm. If $z_{m}$ is high, and for a given number of workers $n_{w}$, then the quantity that can be produced, $q$, is higher.

If the reception of the problem costs $h$ units of a manager's time, the firm needs at least $n_{m}$ managers to deal with the expected number of problems that cannot be dealt with directly by workers:

$$
n_{m}=(h)\left(n_{w}\right) e^{-\left(\frac{1}{\theta}\right) z}
$$

The need of managers to face the unsolved problems, which increases with the number of varieties, is stronger when the firm diversifies its export portfolio. This leads to:

Lemme 1 For a given skill of workers $z$, the need for managers increases with the number of varieties produced by the firm.

Moreover the manager-to-worker ratio then increases in the number of product-destinations $\theta$ and decreases with $z$ :

$$
\begin{gathered}
\frac{\partial\left(n_{m} / n_{w}\right)}{\partial \theta}=\frac{z}{\theta^{2}}(h) e^{-\left(\frac{1}{\theta}\right) z}>0 \\
\frac{\partial\left(n_{m} / n_{w}\right)}{\partial z}=\frac{-1}{\theta}(h) e^{-\left(\frac{1}{\theta}\right) z}<0
\end{gathered}
$$

'Difficult' product-destinations generate a greater number of production-distribution problems that are beyond workers' skills, implying a higher manager-to-worker ratio. ${ }^{11}$ This result can be formulated as follows:

Proposition 1 Export entry requires a higher number of managers, hence more layers.

This proposition is in line with our empirical fact number 1 , and is supported by the evidence presented in Table 6 and 8 (left columns) in the previous section.

Proposition 2 Trade diversification (i.e. a higher $\theta$ ) requires a higher number of managers, hence more layers.

\footnotetext{
${ }^{11}$ Note that this result is independent of the size or scale of the firm for a given $\theta$.
} 
This proposition is in line with our empirical fact number 2, and is supported by the evidence presented in Table 5 in the previous section.

Proposition 3 The number of managers relative to workers is increasing with the scope of a firm's export portfolio $\theta$, and decreasing with the skill level of the workers $z$.

This proposition is in line with our empirical fact number 2 , and is supported by the evidence presented in Table 8 (right columns) in the previous section.

\subsection{The cost function}

Production uses labor as the only variable factor of production. The variable cost function is then:

$$
C(\theta, A, z)=n_{w} \omega+n_{m} k \omega
$$

where $\omega$ is the unit-cost of labor for workers with skill level $z$. Wages of managers are higher, where $k$ is the cost premium associated with their higher skill level.

The firm chooses the value $n_{w}$ that minimizes its cost, subject to two constraints, (6) and (5). The marginal cost of producing and exporting varieties up to item $\theta$ is then (see Proof in the Appendix) :

$$
\begin{gathered}
v(\theta, A, z)=\phi=\frac{\omega}{A\left(1-e^{-\frac{z_{m}}{\theta}}\right)} \\
v(\theta, A, z)=\phi=\omega\left(A-A e^{-\frac{z_{m}}{\theta}}\right)^{-1}
\end{gathered}
$$

In contrast to (4), the relevant skill parameter at the numerator of (11) is the managers' skill level $z_{m}$. This reflects the fact that when workers are assisted by managers, any problem unsolved by workers can be passed through the organization structure up to the upper layer. It is also important to notice that the marginal cost is associated with the total amount of production at the firm level, $q$.

(12) below shows that the marginal cost is increasing with $\theta$ and decreases with the managers' skill $z_{m}$.

$$
\frac{\partial v(\theta, A, z)}{\partial \theta}=\omega\left(A-A e^{-\frac{z_{m}}{\theta}}\right)^{-2}\left(\frac{z_{m}}{\theta^{2}}\right) A e^{-\frac{z_{m}}{\theta}}>0
$$

\subsection{The optimal production level}

In our setting, domestic producers choose to produce a single variety $(\theta=1)$ because they do not benefit from economies of scope. Then, the profit function of domestic producers 
is $\pi(A, z)=\frac{L}{4 \gamma}\left\{v_{D}-\frac{\omega}{A\left(1-e^{-\frac{z_{m}}{\theta}}\right)}\right\}^{2}$. Instead, when $\theta>1$, the firm is no longer a singlevariety type. Production requires to pay a fixed entry cost to enter the foreign market, $G$, regardless of the number of varieties, inducing that firms benefit from economies of scope once they start exporting. Following Ottaviano and Thisse (1999), multi-product firms face an aggregate demand for several varieties, where $q_{i}$ corresponds to the demand for each variety. Thus firm $j$ is facing $q=\int_{i \in \Theta_{j}} q_{i} d i$ where $\Theta_{j}$ is the set of varieties produced by firm $j$, with $\Theta_{j} \in \Omega^{*}$. Then, $\theta_{j}$ is the number of varieties in this set.

Compared to single-product firms, multi-product firms interact with each other through their decision regarding the scope of their varieties relative to the market size. The total number of varieties $\Omega^{*}$ is distributed among $J$ firms facing an identical entry cost $G$ in addition to their labor cost depending on managers skill as in (18).

The profit function for multi-product firms is then:

$$
\pi(m, A, z)=\int_{i \in \Theta_{j}} p_{i} q_{i} d i-n_{w} \omega-n_{m} \omega k-G
$$

We suppose that $p_{i}$ is given to the firm and firms choose to produce a certain number of varieties determining its market share over $\Omega^{*}$. Here we do not consider any impact on price, because the set of varieties is large enough to prevent any firm, clustering a subset of varieties, to affect the average market price.

From (14), we get:

$$
p_{i}=\frac{\alpha \gamma}{\eta N+\gamma}-\frac{\gamma}{L} q_{i}+\frac{\eta N}{\eta N+\gamma} \bar{p}=p_{\max }-\frac{\gamma}{L} q_{i}
$$

Then, introducing (14) in (13)

$$
\begin{gathered}
\pi(\theta, A, z)=\int_{i \in \Theta}\left(p_{\max }-\frac{\gamma}{L} q_{i}\right) q_{i} d i-n_{w} \omega-n_{m} \omega k-G \\
\pi(\theta, A, z)=p_{\max } \int_{i \in \Theta} q_{i} d i-\frac{\gamma}{L} \int_{i \in \Theta} q_{i}^{2} d i-n_{w} \omega-n_{m} \omega k-G
\end{gathered}
$$

Maximizing the profit function relative to $q$ we get the optimal quantity $q^{*}$ at firm-level.

$$
q^{*}=\frac{\theta L}{2 \gamma}\left[p_{\max }-\frac{\omega}{A\left(1-e^{-\frac{z_{m}}{\theta}}\right)}\right]
$$

It shows that the size of the firm is increasing with $\theta$ and also with the manager's skill $z_{m}$. As expected, size increases with productivity and with the size of the market $L$.

Proposition 4 The optimal size increases with trade diversification. It also increases with the manager's skill $z_{m}$. 
The optimal level of $\theta$ is determined by the manager's skill $z_{m}$ which comes from a distribution of managers' skill $Z$ in the market. It creates productivity heterogeneity which determines a firm's ability to trade-diversify. At the equilibrium, this distribution $Z$ drives the total number of varieties and finally the competitiveness of the country and its world market share.

In conclusion, the model provides supports to previous empirical findings. It explains that labor organisation is associated with trade diversification because the latter implies additional problems to deal with. It displays a clear trade-off between the scale effect which motivates the addition of varieties and the organisational cost which implies a higher manager-to-worker ratio. This trade-off is affected by the cost of managers and by their skill level relative to workers. Although dynamics are not directly studied, the model provides insights regarding the change in labor organisation in response to the decision to increase trade diversification. Indeed we expect than the complexity of labor organization and the manager-to-worker ratio are explained by trade diversification. We would also expect that a change in the number of hierarchical layers is associated with a change in trade diversification and specifically that the probability to add a layer of managers increases when firms add new varieties to their portfolio. In the next section, we present some econometric tests of the dynamics suggested by the model.

\section{Explaining the change in the number of managerial layers}

Our preliminary descriptive statistics support the main features described by the model. Exporting firms, and firms with higher trade diversification, have more complex labor organisations. In what follows, we test the dynamic implications of the model. We infer that a firm which decides to augment its number of varieties has to implement organisational changes to face the complexity raised by the enlargement of its varieties scope. Hence the descriptive evidence and the model both suggest that the addition of a layer of managers is positively linked to trade diversification.

More precisely, we obtain three testable hypotheses from the model: 1) Export entry (i.e. $\theta$ increases from 0 to a strictly positive value) requires a higher number of managers, hence increases the probability to add a layer of management; 2) a higher number of varieties requires a higher number of managers, hence increases the probability to add a layer of management; 3) the number of managers relative to workers is increasing with trade diversification.

However, results could be driven by other changes in the firm's characteristics, such as firm size - therefore in what follows we control for firm growth in order to disentangle the organisational changes related to growth vs. changes in the trade patterns.

We start by testing the first proposition related to export entry, then we analyse the 
relation between trade diversification and the probability to add a layer of management, and finally we study the determinants of the ratio of managers relative to workers and test the role of trade diversification.

\subsection{Trade status and the addition of a layer of managers}

Export entry can be considered as the first level of trade diversification, as shown by the model. Indeed, adding a new foreign market to the domestic market is in itself a signal of trade diversification. In what follows we test whether export entry impacts the probability to add a layer of managers. The estimation sample only comprises firms which do not have a layer of management in the previous period. The dependent variable is a dummy variable which takes the value one when the firm adds one layer of managers to its organisational structure. Export entry is a dummy variable which takes the value one in year $t$ if the firm was not exporter in year $t-1$ but does export in year $t$, and zero otherwise. So this specification allows to identify whether export entry into foreign markets is a good explanatory variable of the decision to add a layer of managers, controlling for other covariates which could explain this decision.

To disentangle the "pure" growth from the export diversification channel explaining the addition of a layer of managers, we add the log growth of (deflated) value added to the set of explanatory variables, as well as measure the interaction effect between firm growth and the export entry variable. Additional controls include labor productivity (deflated value added over the number of hours worked), in logs; size (the number of employees), in logs; and the number of occupations (occupational categories defined at the 3-digit level, which can be considered as a measure of idiosyncratic diversification of jobs), in logs. Year and 2-digits level sector fixed effects are also introduced.

Alhough the dependent variable is binary, we start by using the least square dummy variable estimator (LSDV) which allows us to account for firms fixed effects. We also estimate a simple probit where no firm fixed effects are included and where firm performance variables control for heterogeneity. Finally we estimate a probit with random effects.

Results in Table 9 show a positive and significant impact of export entry on the probability to add a layer of managers in all our specifications. For the probit estimator, the coefficients displayed in the table correspond to the marginal effect of a change in the explanatory variable on the probability to add a layer of managers. Hence, entering foreign markets augments the probability to add a layer of managers by 0.008 percentage point. Value added growth is also associated with an increase in the target probability, and we find a complementarity effect of growing and starting to export, leading to an overall impact of export entry of 0.011 points. If growing has, solely, a greater impact on the probability, the regression results support the independent role of trade.

One may think that, still, the control variables are insufficient to capture the unob- 
served heterogeneity which could make the error terms correlated with the regressors. The third column of Table 9 reports the results from a random effects regression. They confirm the initial results.

Table 9: Impact of export entry on the probability to add a layer of management.

\begin{tabular}{lccc}
\hline \hline & \multicolumn{2}{c}{ Dependent Var. : Adding a layer of managers } \\
\cline { 2 - 4 } & LSDV & Probit & RE-Probit \\
\hline & & & \\
Exp. entry & $0.009^{* * *}$ & $0.008^{* * *}$ & $0.098^{* * *}$ \\
Log Growth VA & $-0.002^{* * *}$ & $0.006^{* * *}$ & $0.070^{* * *}$ \\
Gr VA $*$ Exp & $0.012^{* * *}$ & $0.003^{* *}$ & $0.092^{* * *}$ \\
Log Labor Prod. & $0.005^{* * *}$ & $0.001^{* * *}$ & $0.027^{* * *}$ \\
Log Occupations & $0.112^{* * *}$ & $0.072^{* * *}$ & $1.767^{* * *}$ \\
Log Size & $0.001^{*}$ & $-0.004^{* * *}$ & $-0.084^{* * *}$ \\
\hline Year FE & yes & yes & yes \\
Sector FE & yes & yes & no \\
Firm FE & yes & no & no \\
Firm RE & no & no & yes \\
\hline Nb. obs & 956,059 & 956,059 & 956,059 \\
Pseudo R-squared & & 0.21 & - \\
Log-Likelihood Value & & -128 & -127 \\
Rho & - & & $0.62^{* * *}$ \\
\hline \hline
\end{tabular}

Sources: DADS-FARE-Douanes 2009-2014.

Firms with no layer of management in year $t-1$.

\subsection{Trade diversification and the addition of a layer of managers}

We now focus on exporters only (those present in the Customs dataset, cf. sample 2) and we test the explanatory power of trade diversification with respect to the probability to add a layer of management. We use the relative number of new varieties - which is the share of new varieties relative to the total of varieties a firm exports - as our measure for change in trade diversification. The number of varieties is not in itself an appropriate measure of diversification because firms may drop products while adding a new one, or re-export an older one. We choose then to count the number of new varieties each year. As previoulsy defined, a new variety in $t$ is such that it was present in the variety portfolio of the firm the years before $t$ (for the years we observe in our dataset).

In Table 10, we compute two sets of probit regressions, alternatively considering varieties at the NC8 or SH4 disaggregation levels. In each set, we use as dependent variables i) the addition of a new variety; ii) the share of new varieties; iii) we also consider a change in the Herfindhal index (see Table 6).

It turns out that the diversification decision increases the probability of adding a layer of managers by 1 percentage point when varieties are observed at the 8-digits level and by 1.3 percentage point when varieties are observed at the 4 digits level (columns (1) and 
(4)). When considering the impact of the share of a new varieties, the impact rises to 2.5 percentage points at the 8-digits level and 2.7 at the 4-digits level. A specification with the change in the Herfindhal index allows to evaluate both the evolution in the portfolio of varieties and the extent of such change. Coefficients are as expected negative but weaker compared to the previous measures. Note that the coefficient is non significant in column (8). As the regression controls for firm growth and other idiosyncratic characteristics, we can conclude that trade diversification has a specific positive impact on the probability to add managers.

The comparison of the coefficients' magnitude across the two levels of product disaggregation tests one of the hypothesis from the model. In the model we assume that the higher complexity implied by diversification, the higher the likelihood it affects the relative number of managers. Since at the four digits level, a new variety is likely to demand more different production processes than a "novelty" only observed at the 8 digits level, we expect the impact of "novelty" on the probability to add a layer of managers to be higher at the 4-digits level. Indeed we confirm this expectation and observe higher marginal effects in columns (4) and (5) compared to columns (1) and (2).

\subsection{Trade diversification and the ratio of managers}

In this section we focus on the ratio of managers with respect to workers as a measure of labor organisation. From the model, we expect the ratio to rise in response to trade diversification (cf. Prop. 3). Contrary to previous measures of labor organisation, this one is continuous and captures the intensity in management functions relative to production functions (the latter referring to workers who execute the productive orders). By considering the continuous variable of management functions change, we want to check whether trade diversification changes explain the change in the ratio of managers within the firm. Table 11 shows results of a panel regression using firm fixed effects, considering three measures of trade diversification changes $(\Delta T D)$. In columns (1) and (3), we use the share of new varieties observed at 8-digits or 4-digits levels. In column (2), we consider a change in the herfindhal indicator of trade diversification when varieties are observed at the 8-digits level. As previously mentioned, the Herfindhal indicator captures both the addition of new varieties but also the share of the new variety in total exports. We also include in the regression the discrete event of adding a ratio of managers (Adding), as well as the interaction variable with the trade diversification indicator.

Results show that trade diversification has a positive impact on the ratio of managers when it is combined with a change in the organisation. In other words, the addition of a layer of managers has a positive impact on the ratio of managers but the positive effect is augmented when the firm diversifies its export portfolio of varieties. 


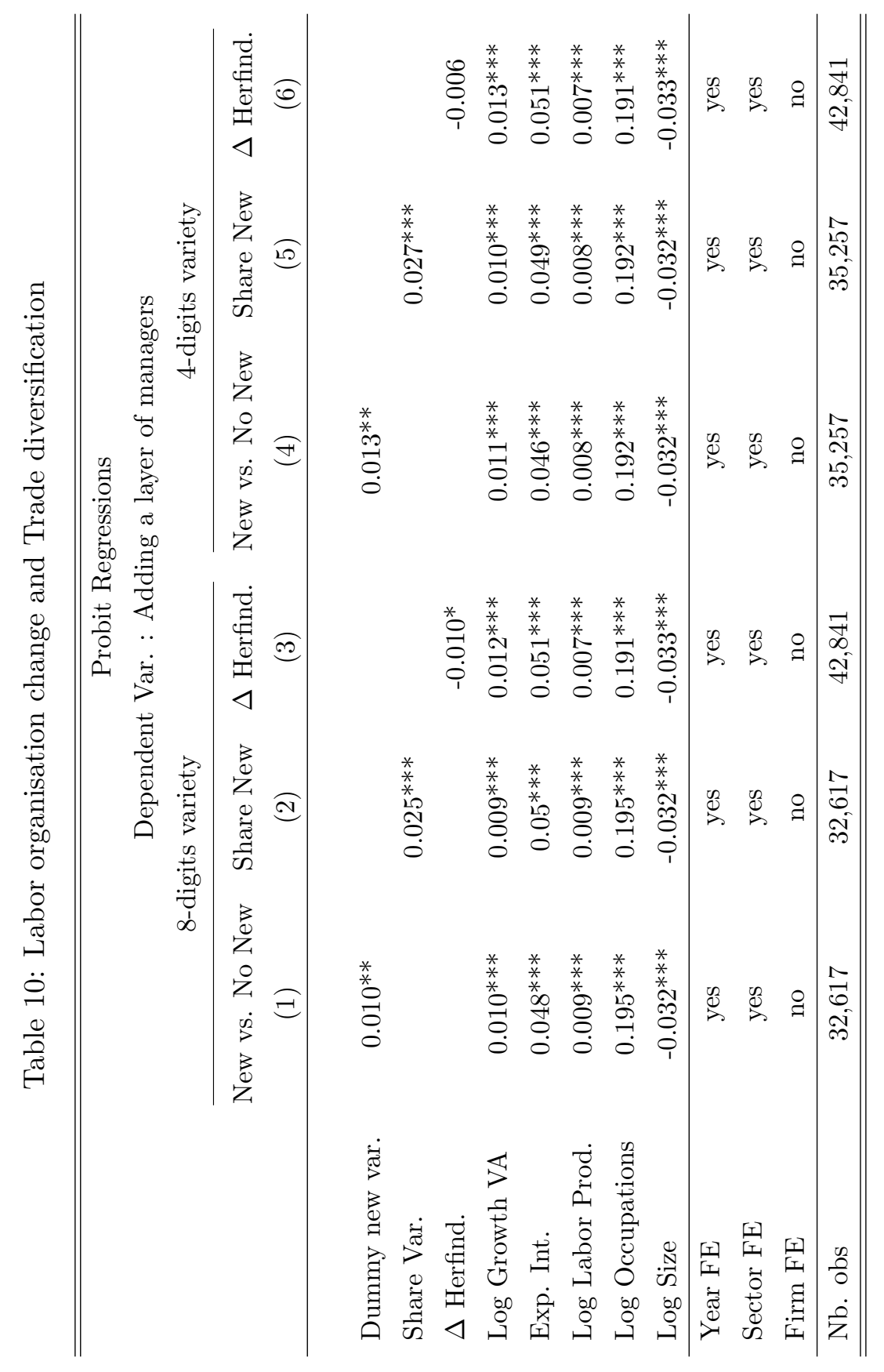


Table 11: Ratio of managers and trade diversification

\begin{tabular}{|c|c|c|c|}
\hline & \multicolumn{2}{|c|}{ 8-digits variety } & \multirow{2}{*}{$\begin{array}{c}\text { 4-digits variety } \\
\text { Share new var. } \\
\text { (3) }\end{array}$} \\
\hline & $\begin{array}{c}\text { Share new var. } \\
\text { (1) }\end{array}$ & $\begin{array}{c}\Delta \mathrm{HHI} \\
(2)\end{array}$ & \\
\hline Adding & $0.139^{* * *}$ & $0.138^{* * *}$ & $0.143^{* * *}$ \\
\hline$\Delta T D$ & -0.002 & -0.001 & -0.003 \\
\hline$\Delta T D \times$ Adding & $0.020^{* *}$ & $0.022^{*}$ & $0.022^{*}$ \\
\hline Year FE & yes & yes & yes \\
\hline Sector FE & no & no & no \\
\hline Firm FE & yes & yes & yes \\
\hline Nb. obs & 249,385 & 263,385 & 216,328 \\
\hline
\end{tabular}

\section{Conclusion}

This study investigates the impact of export expansion (i.e. trade diversification) on the labor structure of firms, testing empirically the results from a model describing the costcomplexity trade-off faced by exporting firms.

We found that the organisational structure of exporting firms is more complex than that of non-exporting firms, as they present a higher probability to have a layer of management on average. Exporting is associated with a higher share of managers.

Our empirical results support the main features described by the model. A firm which decides to enter foreign markets or to augment its number of export varieties has to implement organisational changes to face the complexity raised by the enlargement of its scope of varieties. First we identify the impact of trade status on the labor organisation of a firm, measured by the likelihood to add a layer of managerial occupations. We show that export entry has a different impact on labor organization than merely a change in size (here, value added growth). Our results support a positive relationship between a firm's trade diversification and the likelihood it changes its labor organisation. We find that firms expanding their export portfolio have a higher probability to add managerial layers, after controlling for firm growth. Finally, and in line with our model, the ratio of managers with respect to other workers increases when the portfolio of exported products and destinations expands. Overall, we obtain a body of evidence which supports a positive relation between trade diversification and change in labor organisation through the addition of layers of management.

Further improvement of the model include predictions regarding the relation between wage dispersion and labor organization, and their link with trade behaviour. We expect that firms' trade commitment and specifically trade diversification increase intra-firm wage inequality. In other words, the addition of managers when expanding the trade portfolio could be another channel through which trade increases wage inequality. Our research 
agenda also relates to the import activity of the firm, which may have a non-negligible effect on its labor organisation. 


\section{References}

Amiti, M. and Davis, D. R. (2012). Trade, firms, and wages: Theory and evidence. The Review of Economic Studies, 79 (1), 1-36.

Baumgarten, D. (2013). Exporters and the rise in wage inequality: Evidence from German linked employer-employee data. Journal of International Economics, 90 (1), 201-217.

Bender, S., Bloom, N., Card, D., Van Reenen, J. and Wolter, S. (2017). Management practices, workforce selection and productivity. Journal of Labor Economics.

Bernard, A. B. and Jensen, J. B. (1997). Exporters, skill upgrading, and the wage gap. Journal of International Economics, 42 (1-2), 3-31.

-, Redding, S. J. and Schott, P. K. (2010). Multiple-product firms and product switching. American Economic Review, 100 (1), 70-97.

Biscourp, P. and Kramarz, F. (2007). Employment, skill structure and international trade: Firm-level evidence for France. Journal of International Economics, 72 (1), 2251.

Bustos, P. (2011). Trade liberalization, exports, and technology upgrading: Evidence on the impact of MERCOSUR on Argentinian firms. The Americal Economic Review, 101 (1), 304-40.

Caliendo, L., Monte, F. and Rossi-Hansberg, E. (2015). The anatomy of french production hierarchies. Journal of Political Economy, 123 (4), 1393-1467.

- and Rossi-Hansberg, E. (2012). The impact of trade on organization and productivity. The Quarterly Journal of Economics, 127 (3), 1393-1467.

Caselli, M., Chatterjee, A. and Woodland, A. (2014). Multi-product exporters, variable markups and exchange rate fluctuations. Discussion Papers 2014-15, School of Economics, The University of New South Wales.

Das, S., Roberts, M. J. and Tybout, J. R. (2007). Market Entry Costs, Producer Heterogeneity, and Export Dynamics. Econometrica, 75 (3), 837-873.

Eckel, C. and Neary, J. P. (2010). Multi-Product Firms and Flexible Manufacturing in the Global Economy. Review of Economic Studies, 77 (1), 188-217.

EgGer, P. H. and Lassmann, A. (2015). The causal impact of common native language on international trade: Evidence from a spatial regression discontinuity design. The Economic Journal, 125 (584), 699-745.

Helpman, E., Itskhoki, O. and Redding, S. (2010). Inequality and unemployment in a global economy. Econometrica, 78 (4), 1239-1283.

IACovone, L. and JavorciK, B. S. (2010). Multi-product exporters: Product churning, uncertainty and export discoveries*. The Economic Journal, 120 (544), 481-499.

Iodice, I. and Tomasi, C. (2015). Skill Upgrading, Wage Gap and International Trade: 
Firm-level Evidence for Italian Manufacturing Firms. Tech. Rep. 2015/06, Laboratory of Economics and Management (LEM), Sant'Anna School of Advanced Studies, Pisa, Italy.

Kugler, M. and Verhoogen, E. (2012). Prices, plant size, and product quality. The Review of Economic Studies, 79 (1), 307-339.

MARIn, D. and Verdier, T. (2014). Corporate hierarchies and international trade: Theory and evidence. Journal of International Economics, 94 (2), 295-310.

Mayer, T., Melitz, M. J. and Ottaviano, G. I. (2014). Market size, competition, and the product mix of exporters. The American Economic Review, 104 (2), 495-536.

Moxnes, A. (2010). Are sunk costs in exporting country specific? Canadian Journal of Economics, 43 (2), 467-493.

Ottaviano, G. and Thisse, J.-F. (1999). Monopolistic Competition, Multiproduct Firms and Optimum Product Diversity. CEPR Discussion Papers 2151, C.E.P.R. Discussion Papers.

Roberts, M. J. and Tybout, J. R. (1997). The Decision to Export in Colombia: An Empirical Model of Entry with Sunk Costs. American Economic Review, 87 (4), 545-64.

Serti, F., Tomasi, C. and Zanfei, A. (2010). Who trades with whom? Exploring the links between firms' international activities, skills, and wages. Review of International Economics, 18 (5), 951-971.

Verhoogen, E. A. (2008). Trade, quality upgrading, and wage inequality in the Mexican manufacturing sector. The Quarterly Journal of Economics, 123, 489-530.

YeAPle, S. R. (2005). A simple model of firm heterogeneity. Journal of International Economics, 65, 1-20. 


\section{A Proof of (18)}

Starting from the following cost function:

$$
C(\theta, A, z)=n_{w} \omega+n_{m} k \omega
$$

We minimise the cost function relative to $n_{\omega}$ under two constraints, given by (5) and (6). The Lagrangian to minimize is then :

$$
\min \{L(\theta, A, z)\}=\min \left\{n_{w} \omega+n_{m} k \omega+\phi\left[q^{j}-A\left(1-e^{-\frac{z_{m}}{\theta}}\right) n_{w}\right]\right\}
$$

Let suppose that $n_{m}=1$, then $n_{w}$ is the number of workers per manager. The relation between managers and workers are then:

$$
n_{w}=\frac{1}{h} e^{\left(\frac{1}{\theta}\right) z}
$$

Substituting in (21), we get:

$$
\begin{gathered}
\min \{L(\theta, A, z)\}=\min \left\{n_{w} \omega+k \omega+\phi\left[q-A\left(1-e^{-\frac{z_{m}}{\theta}}\right) \frac{e^{\frac{z}{\theta}}}{h}\right]\right\} \\
\frac{\partial L}{\partial n_{w}}=\omega-\phi A\left(1-e^{-\frac{z_{m}}{\theta}}\right)=0
\end{gathered}
$$

Hence, from this equation, we can extract the value of $\phi$, the marginal cost of production $\left(\frac{\partial L}{\partial q}\right)$ :

$$
v(\theta, A, z)=\phi=\frac{\omega}{A\left(1-e^{-\frac{z_{m}}{\theta}}\right)}
$$

Note that it increases with $\theta$ and decreases with the managers' skill. 